\title{
REVITALISING INDONESIAN ISLAMIC BANKING PERFORMANCE: A STAKEHOLDER ANALYSIS
}

\author{
Ruspita Rani Pertiwi ${ }^{1}$, Jann Hidajat Tjakratmadja ${ }^{2}$ and Hary Febriansyah ${ }^{3}$ \\ ${ }^{1}$ Islamic State University of Sunan Kalijaga, School of Business and Management, Institute \\ Technology of Bandung, Indonesia, ruspita.pertiwi@uin-suka.ac.id \\ ${ }^{2}$ School of Business and Management, Institute Technology of Bandung, Indonesia, \\ jannhidajat@sbm-itb.ac.id \\ ${ }^{3}$ School of Business and Management, Institute Technology of Bandung, Indonesia, \\ hary@sbm-itb.ac.id
}

\begin{abstract}
This paper examines the views of Islamic bank stakeholders, which are used as basis for measuring and improving bank performance. Taking Indonesia as a case study, we compile information and data from both internal and external stakeholders through in-depth interviews and focus group discussions, code them using N-Vivo, and finally apply a stakeholder management framework for the data analysis. The results obtained suggest that internal stakeholders' views of Indonesian Islamic banking performance are relatively positive. However, external stakeholders tend to have varied views of its performance. The research finds that the religious values promoted by Islamic banks can increase company value, but at the same time they can also reduce interest in Islamic banking. Based on these findings, it is necessary to investigate further how to strategise the religious values for the promotion of Islamic banking.
\end{abstract}

Keywords: Performance, Management, Banking.

JEL classification: G18; G21; G28.

Article history:

Received : October 8, 2020

Revised : April 6, 2021

Accepted : June 24, 2021

Available online : November 30, 2021

https://doi.org/10.21098/jimf.v7i4.1373 


\section{INTRODUCTION}

\subsection{Background}

Issues related to company performance have been extensively explored as main themes in management and organisation sciences. For Islamic banks, as they are newcomers in the financial industry and are underpinned by religious values and Shariah principles, measuring their performance against that of well-established conventional banks is critical and has been the subject of wide discussion. The key issue is whether the application of Shariah principles by Islamic banks affects organisational performance; see, amongst others, Beck, Demirgüç-Kunt, \& Merrouche (2013), Hanif, Tariq, Tahir, \& Wajeeh-ul-Momeneen (2012), Johnes, Izzeldin, \& Pappas (2014), Mollah \& Zaman (2015), and Siraj \& Sudarsanan Pillai (2012).

The definition of the organisational success of an Islamic bank (IB) varies, ranging from financial success (Rosly \& Abu Bakar, 2003; Eljelly \& Abdelgadir Elobeed, 2013; Harfiah, Purwati, \& Ulfah, 2016; Rafiq, 2016; Rodoni et al., 2017; Hassan \& Aliyu, 2018) to management success (Huda, Sabrina, \& Zain, 2013; Tariq, Ahmed, Rafi, \& Ahmed, 2014) and success in terms of social contributions (Faliza, 2016; Gustani, 2013; Zafar \& Sulaiman, 2020). Apart from these dimensions of success, some studies have centered their discussion of IB success on the meeting of Sharia principles (Ascarya, Rahmawati, \& Sukmana, 2017; Bedoui \& Mansour, 2015; Mohammed, Tarique, \& Islam, 2015; Rusydiana \& Hasib, 2019; Syafii Antonio, Sanrego, \& Taufiq, 2012). Mostly, Islamic banking performance is measured by quantified indexes or ratios constructed from internally provided data from financial and annual reports. In this study, we measure Islamic banking performance using qualitative data based on stakeholders' perspectives, with a focus on Indonesian Islamic banks.

Starting with the first Islamic bank in 1992, Indonesia has had great expectations of its Islamic banking industry. This stems from the fact that $80 \%$ of the country's population is Muslim and that Indonesia is the country with the most significant number of Muslims in the world (Lipka \& Hackett, 2017). As of October 2019, there were 14 Islamic Commercial Banks (BUS) and 20 Islamic Business Units (UUS 'in Indonesia'). In this period of 2019, the year-to-year growth in IB assets was 10.15 percent (YoY). The Compounded Annual Growth Rate (CAGR) of Islamic banking was even higher, at 15 per cent. Comparatively, the national banking industry's CAGR stood at 10 percent during the same period (OJK, 2019).

Despite the fast growth of Islamic banking, the market or asset share of Islamic banks in Indonesia remains low. Total IB assets in October 2019 were IDR 499.98 trillion, which is far below the level of conventional banking assets of IDR 8,648 trillion (OJK, 2019). In line with these figures, the market share of IB assets is only 6.1 percent OJK recently released the National Financial Literacy Survey results (SNLK, 2019), showing an Islamic financial literacy index of 8.93 per cent and a Sharia financial inclusion index of $9 \%$ (Puspaningtyas, 2019). Therefore, in relation to the Indonesian market, knowledge of, familiarity with, and access to Islamic banking is far from being satisfactory. This means that for Islamic banks to improve their performance, especially in the eyes of their stakeholders, stakeholder analysis is of critical importance for them to understand the root causes of any lack of acceptance, as indicated by market knowledge and familiarity. For this reason, an in-depth qualitative study is required. 
Stakeholder analysis also provides information for management to understand which stakeholders have an interest in their bank, which will be useful for establishing appropriate and targeted strategies in the future. On this basis, stakeholder analysis can be a tool that helps management to analyse the company's key stakeholders. Understanding stakeholders' perspectives allows companies to recognise their position in the eyes of the market, thus helping them to determine their strategies (Bunn, Savage, \& Holloway, 2002; Payne, Ballantyne, $\&$ Christopher, 2005). Such understanding also plays a role in the value creation process (Clarkson, 1995; Frow \& Payne, 2011; Preston \& Sapienza, 1990; Tantalo \& Priem, 2016), which in turn improves organisational performance (Clarkson, 1995; He, Zhang, Li, \& Piesse, 2011; Soto, Quintana, \& Rodríguez, 2018). This paper therefore provides an analysis of Islamic banking performance from the perspectives of various stakeholders.

\subsection{Objective}

The study examines Islamic banking performance in Indonesia through the lens of stakeholders. The findings are expected to provide (1) an Indonesian context for Islamic banking performance; (2) a basis for revitalising Islamic bank strategy; and (3) guidance on policy-making for the development of Islamic banks. The study propose stakeholder analysis and how it can be a measure of organisational performance and a basis for revitalising corporate strategy.

\section{LITERATURE REVIEW}

\subsection{Stakeholders}

The concept of stakeholders started in the early 1930s in the United States, where the General Electric Company identified four major interest groups that needed to be considered: customers, employees, the general public, and shareholders (Preston \& Sapienza, 1990). In 1963, the Stanford Research Institute defined stakeholders as "those groups without whose support the organization would cease to exist" (Littau, Jujagiri, \& Adlbrecht, 2010). A book entitled Strategic Management: A Stakeholder Approach by Freeman is widely recognized as the foundation of stakeholder theory. It defines stakeholders as "any group or individual who can affect or is affected by the achievement of the organization's objectives (Freeman, 1984).

Stakeholders are also defined in a broad general sense and in a narrow sense (Mitchell, Agle, \& Wood, 1997). In the general sense, they are individuals or groups who can influence the achievement of company goals and have a mutual relationship. On the other hand, from a narrower point of view, stakeholders are parties on which a company depends to ensure its sustainability. The interests of each stakeholder may be different, so the assertiveness and flexibility of companies to respond to a variety of interests are required.

The term "stakeholder" can be defined as an individual or group that has a legitimate interest in a company. There are several categories of stakeholders, including internal-external ones and primary-secondary ones. Based on the stakeholders' position in company management, they can be categorised as either 
internal or external. Internal stakeholders, such as employees, management, and boards of directors, are entities within a business, whereas external ones are not within located the business itself, but which care about or are affected by its performance. Based on the boundaries of what constitutes a stakeholder, they can be categorised as primary or secondary (Clarkson, 1995; Waddock \& Smith, 2000). Primary stakeholders are those groups on whom the firm depends for its survival and continued success. On the other hand, secondary stakeholder groups do not have a contractual obligation with the firm nor exercise any legal authority over it (Eesley \& Lenox, 2006).

\subsection{Previous Studies}

Along with the increasing interest of academics in the discussion of stakeholders, there is also growing awareness that a company is an entity that not only operates in its own interests, but also provides benefits to others, in particular its stakeholders. This has led to debate on the competing objectives between shareholders and stakeholders (Pedrini \& Ferri, 2019) and on how to build on their mutual benefits (Berman, Wicks, Kotha, \& Jones, 1999). Another issue that has arisen is the inability of a company to sustain growth alone without building relationships with its different stakeholders and responding to their expectations (Atti et al., 2019; Bhattacharya et al., 2009; Freeman, 1984; Freeman, 2015; Littau et al., 2010; Minoja, 2012; Pedrini \& Ferri, 2019).

Recent studies have focused on the influence of stakeholder management on company performance by exploring how stakeholders' perspectives and views could improve business objectives (Matos \& Silvestre, 2013; Ranängen \& Zobel, 2014) and in the long run play an essential role in company sustainability (Perrini \& Tencati, 2006; Soto et al., 2018; Wojewnik-Filipkowska et al., 2019). The influence of stakeholder management on company performance and sustainability takes place because stakeholder management is the basis for the value creation process (Frow \& Payne, 2011; Hult et al., 2011; Tantalo \& Priem, 2016; Wojewnik-Filipkowska et al., 2019); for improving decision making (Hult et al., 2011; Minoja, 2012; Soto et al., 2018; Pedrini \& Ferri, 2019); and for integration into company strategy (de Colle, 2005; Frooman, 1999; Minoja, 2012). Regarding company strategy, stakeholder management can be integrated into the strategy development process, strategy execution, and performance measurement (Pedrini \& Ferri, 2019), which can be a basis for revitalising the strategy.

This paper combines stakeholder analysis and stakeholder management as tools to measure organisational performance from all perspectives.

\subsection{Conceptual Framework}

Stakeholder analysis is an approach, a tool or set of tools for generating knowledge about actors, both individuals and organisations, to understand their behaviour, intentions, interrelations and interests, and to assess the influence and resources they bring to bear on decision-making or implementation processes (Brugha \& Varvasovszky, 2000). A stakeholder analysis approach can be used to understand the importance and nature of various stakeholder groups and their impact on market development. 
Stakeholder analysis involves a five-step process: (1) identify key stakeholders; (2) describe the essential characteristics of each stakeholder; (3) analyse and classify the stakeholders according to their attributes; (4) examine the dynamic relationships between the stakeholders; and (5) evaluate generic stakeholder management strategies (Varvasovszky \& Brugha, 2000). Many tools can be used to analyse stakeholders. This study employs salience stakeholder classifications, typology of dependence between stakeholders and companies, and power interest grid analysis. The research framework employed in the study is shown in Figure 1.

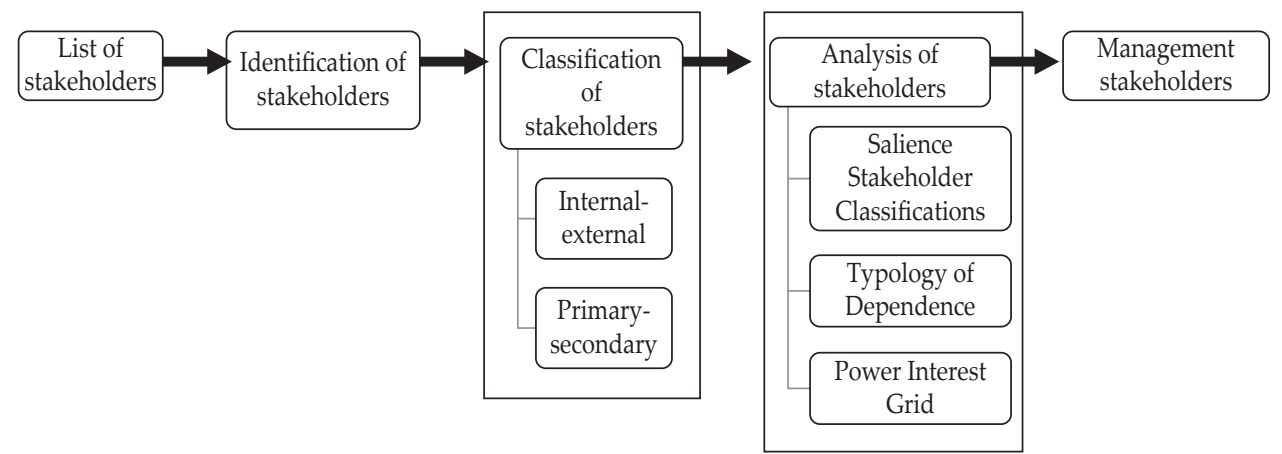

Source: adapted from Varvasovszky and Brugha (2000)

Figure 1.

Research Framework

Salience stakeholder classifications are formed from a mixture of three fundamental attributes, power, legitimacy, and urgency, based on their salience towards the company (Mitchell et al., 1997). The typology of stakeholders is based on three primary attributes, namely: (1) latent stakeholder - a typology that has only one attribute, including the dormant stakeholder (power), discretionary stakeholder (legitimacy), and demanding stakeholder (urgency); (2) stakeholder expectant - having typology - a combination of two attributes, including dominant stakeholders (power and legitimacy), dependent stakeholders (legitimacy and urgency), and dangerous stakeholders (urgency and power); and (3) definitive stakeholder - a typology that contains all three stakeholder attributes, so that with the highest level of salience the voice of this stakeholder group will dominate and often has a significant effect on company performance.

The typology of dependence provides guidelines for analysing the dependence between stakeholders and companies through specific typologies (Frooman, 1999). The matrix describes which stakeholders depend on the company, and vice versa. The relationship between the company and stakeholders can be divided into four characteristics, namely low interdependence, firm power, stakeholder power, and high interdependence. The power interest grid is a type of mapping to determine the classification of stakeholders based on the relationship between the power and interest possessed by the relevant stakeholders (Gardner, Rachlin, \& Sweeny, 1987). The matrix explains the four quadrants of stakeholders based on the mapping results of their power and interests, namely minimum effort, keep informed, keep satisfied, and key player quadrants. 


\section{METHODOLOGY}

Based on the literature review and observations of Indonesian Islamic banks, the paper suggests a breakdown of their stakeholders, as shown in Figure 2. Seven main stakeholders are identified, namely management, employees, government or regulators, customers, society, competitors, and IB associations or non-government organizations. Shareholders are not included here because only two Islamic banks are publicly listed, namely BRIS and Bank Panin Syariah.

The data collection was conducted over five months, from December 2019 to April 2020. The sample for the internal stakeholders comprised three Islamic banks: Bank Syariah Mandiri as the market leader, BNI Syariah as a market challenger, and Bank Aceh Syariah as a regional Islamic bank. The total number of internal samples was 20 respondents; details of their characteristics are presented in Table 2. External stakeholders consist of customers, society, competitors, and IB associations. Customers in the research consisted of five groups, namely (1) Islamic banking customers; (2) conventional banking customers; (3) customers with accounts in IB or CV; (4) entrepreneurs who use banking services; and (5) non-Muslim customers.

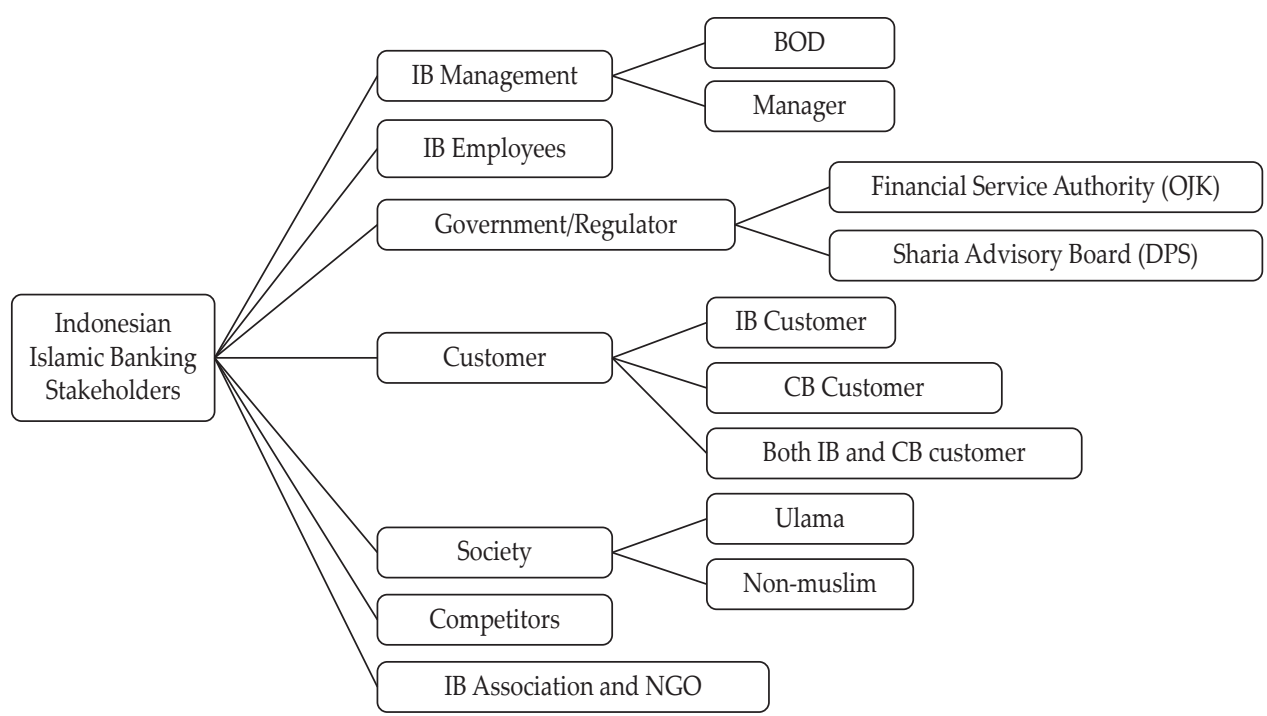

Figure 2.

Indonesian Islamic Banking Stakeholders

The study used semi-structured interviews for data compilation. Face-to-face interviews, focus group discussions and phone interviews were also conducted. Semi-structured interviews were held, which are appropriate for uncovering hidden or emerging themes (Magaldi, 2020).

The nature of the study is narrative. Narrative inquiry is a form of qualitative research in which the stories themselves become the raw data (Butina, 2013; Creswell, 2013; Savin-Baden \& Van Niekerk, 2007). Defining features of the narrative approach include the collection of narratives (stories) from individuals or small groups, so the instruments for the data collection were semi-structured interviews, FGDs, and observation. 
Qualitative data analysis is simply "the process of making sense out of the data" (Merriam \& Tisdell, 2016). It is applied to capture the views and the contextual conditions (social, institutional, and environmental) under which the participants operate and hence can provide insights into what led to particular events or outcomes (Yin, 2016). Segments were then compared to look for patterns/ themes in the data (Butina, 2013). The narrative data were coded using N-vivo 12 to separate categories and find the main indicators of Islamic banking performance from the stakeholder perspective. To ensure validity, the coding process was performed by two researchers (inter-raters).

\begin{tabular}{|c|c|c|}
\hline \multicolumn{1}{|c|}{ Data Gathering } & \multicolumn{1}{|c|}{ Data Processing } & \multicolumn{1}{c|}{ Data Analysis } \\
\hline 1. Identifying Stakeholder & 4. Transcribe \& Translate Voice Interview & 7. Stakeholder Analysis \\
\hline 2. Design Interview Guide & 5. Coding using Nvivo & 8. Stakeholder Quadrant \\
\hline 3. Interview with the stakeholder & 6. Stakeholder Perspective on IIB & 9. Revitalization Strategy \\
\hline 1 & & \\
\hline $\begin{array}{l}\text { Ethics: Institution permit \& informed } \\
\text { consent before (3) } \\
\text { Triangulation: people (2 interviewer), } \\
\text { time, and space (via phone, email, } \\
\text { face to face interview) }\end{array}$ & $\begin{array}{l}\text { Triangulation: coding process done by } \\
\text { two researcher (inter-rater) (5) } \\
\text { (6) Is the answer of research question 1 }\end{array}$ & $\begin{array}{l}\text { (9) Is the answer of research } \\
\text { question 2 }\end{array}$ \\
\hline
\end{tabular}

Figure 3.

Research Design

The first stage of the research involved three main steps: identifying and determining Islamic banking stakeholders; compiling a list of questions for the interviews; and contacting and interviewing the respondents. The questions for the interview are shown in Yable 1. To ensure their validity, the interview protocol refinement (IPR) framework of Castillo-Montoya (2016) was used.

Table 1.

\section{Interview Questions}

\begin{tabular}{|c|c|c|}
\hline No & Stakeholder & Interview Questions \\
\hline 1. & $\begin{array}{c}\text { Internal } \\
\text { Stakeholder }\end{array}$ & $\begin{array}{l}\text { 1. What is your position in the IB? Was this your own choice/assignment? } \\
\text { 2. What are your expectations of the IB where you work? } \\
\text { 3. Have your expectations been fulfilled? } \\
\text { 4. How do you view the development of the IB today? }\end{array}$ \\
\hline 2. & $\begin{array}{l}\text { Customer and } \\
\text { Non-Customer } \\
\text { Stakeholder }\end{array}$ & $\begin{array}{l}\text { 5. With which bank are you currently a customer? } \\
\text { 6. What are your considerations in choosing a bank? } \\
\text { 7. Are you satisfied with the bank of your choice? } \\
\text { 8. How do you view the development of IB? } \\
\text { 9. Do you have experience with IB? At what stage? } \\
\text { 10. Are you satisfied with your experience of the IB? }\end{array}$ \\
\hline 3. & $\begin{array}{l}\text { Non-user } \\
\text { Stakeholder }\end{array}$ & $\begin{array}{l}\text { 11. What is your position now? } \\
\text { 12. How do you view the development of IB? } \\
\text { 13. What are your hopes for IB? } \\
\text { 14. What is your role in IB? }\end{array}$ \\
\hline
\end{tabular}


The second stage involved the data processing. The results of the interviews were transcribed and translated from Indonesian into English by the research team. This step in the analysis was designed to increase accuracy and minimise the possibility of bias. In this stage, we used N-Vivo 12 (Nvivo, 2018) to sort and cluster the interview transcripts into several sub-categories that represented each interviewee group. After deciding these, they were grouped into categories; from these, the stakeholders' perspectives of Islamic banks were acquired.

Finally, in the third stage, data analysis was conducted using stakeholder analysis, a tool that helps companies identify and assess the influence and role of certain parties or groups on company activities. The data were obtained from various channels, including interviews with top-level management, discussions with employees and other stakeholders, researcher observation, and external company publications.

The process of collecting and processing the data paid attention to research ethics, such as securing a research permit from the institution and informed consent, both in writing, and interview records showing participants' willingness to be interviewed and guarantees of the confidentiality of their data. Data and methodology triangulation was employed to ensure validity and reliability. The data triangulation was based on various types of data sources and evidence from different situations (Denzin, 2018). Three subtypes of data were identified, namely people, time, and space, which were further explored by interviewing more than one person for the characteristics of each subject, using different interview times, and conducting interviews both offline and online. The methodology triangulation combined interviews, observation, and desk research using varied secondary sources.

The detailed characteristics of the respondents were adjusted to fit the research needs (Table 2). The selection of the first research subjects was determined by the purposive sampling technique. Subsequently, after identifying appropriate respondents with the required characteristics for the study, we then obtained the next respondents using the snowballing method.

Table 2.

Respondent Characteristics

\begin{tabular}{|c|c|c|c|}
\hline Stakeholders & Position & Category & $\begin{array}{l}\text { Number of } \\
\text { participants }\end{array}$ \\
\hline \multirow{8}{*}{ Internal } & \multirow{2}{*}{$\begin{array}{l}\text { Board of } \\
\text { Directors }\end{array}$} & Director & 1 \\
\hline & & Vice President & 2 \\
\hline & \multirow{4}{*}{ Manager } & Strategic Business Division & 2 \\
\hline & & Service \& Networking Division & 3 \\
\hline & & Human Capital Division & 3 \\
\hline & & Knowledge Management Division & 3 \\
\hline & Employee & Various departments from three banks & 6 \\
\hline & & Total Internal Stakeholders & 20 \\
\hline
\end{tabular}


Table 2.

Respondent Characteristics (Continued)

\begin{tabular}{|c|c|c|c|}
\hline Stakeholders & Position & Category & $\begin{array}{l}\text { Number of } \\
\text { participants }\end{array}$ \\
\hline \multirow{11}{*}{ External } & \multirow[b]{2}{*}{ Government } & Financial Service Authority (OJK) & 1 \\
\hline & & $\begin{array}{l}\text { National Sharia Supervisory Board } \\
\text { (DSN) }\end{array}$ & 1 \\
\hline & Competitor & CB Employee & 3 \\
\hline & \multirow{4}{*}{ Customer } & IB Customer & 6 \\
\hline & & Both IB \& CB & 3 \\
\hline & & Entrepreneur & 3 \\
\hline & & CB Customer & 6 \\
\hline & \multirow[t]{4}{*}{ Society } & Other Religion & 3 \\
\hline & & Ulama & 2 \\
\hline & & Total External Stakeholders & 28 \\
\hline & & Total Stakeholders & 48 \\
\hline
\end{tabular}

Thefirstinterviews were conducted with representatives of internalstakeholders consisting of three Islamic banks, the market leader, a market challenger, and a regional Islamic bank. The internal Islamic banking stakeholders included three management levels: top management, namely the board of directors (director and vice president); middle-level management, namely managers (strategic business, service-networking, human capital, and knowledge management division); and the staff level, namely employees from various departments.

The next stage invloved interviews with external stakeholders. Due to the Covid-19 situation, these were conducted remotely by telephone. The duration of interviews ranged from 15 minutes to two and a half hours. Interviews with 28 external stakeholders were also held to gain a complete picture of the situation, including Islamic banking customers, non-Islamic banking customers, regulators/government officials, IB competitors (in this case, CB employees), IB and $\mathrm{CB}$ customers from the entrepreneur community, and finally non-Muslim communities.

\section{RESULTS AND ANALYSIS}

\subsection{Classification of IIB Stakeholders}

Stakeholder classification is useful for determining stakeholders according to their function or interest in the company. From the list of company stakeholders and the results of the interviews, the Islamic banking stakeholders were divided into internal-external (Table 3) and primary-secondary groups (Table 4). 
Table 3.

Indonesian Islamic Banking Stakeholders

\begin{tabular}{lc}
\hline Internal Stakeholders & External Stakeholders \\
\hline Board of Directors & Government/Regulator \\
\hline Management & Society \\
\hline Employees & Ulama, Competitors, \\
\hline
\end{tabular}

Internal stakeholders are parties within the company who are directly involved in its business operations. On the other, external stakeholders are not included in the company's organisational structure and are not directly involved in its activities (Brugha \& Varvasovszky, 2000; Friedman \& Miles, 2002; Hult et al., 2011). IB internal stakeholders include management (in this case, top and middle management) and employees, while there are six external stakeholders, namely customers, government, society, ulamas (Islamic scholars), competitors, and IB associations and NGOs.

Table 4.

Indonesian Islamic Bank Primary and Secondary Stakeholders

\begin{tabular}{lc}
\hline Primary Stakeholders & Secondary Stakeholders \\
\hline Customers & Society \\
\hline Government/regulator & Ulama \\
\hline Management & Competitors \\
\hline Employees & IB associations and NGOs \\
\hline
\end{tabular}

Primary stakeholders are parties who have an economic interest in the company and are willing to take risks, while secondary ones are not closely related to the entity and do not have direct access to the company (Bunn et al., 2002; Hult et al., 2011). Each company has different primary and secondary stakeholders, depending on its characteristics and environmental conditions. Primary stakeholders in IB are management, employees, customers, and the government, while secondary stakeholders include society, ulama, competitors, IB associations, and NGOs.

\subsection{Stakeholders' Perspective of Indonesian Islamic Banking}

\subsubsection{Internal Stakeholders}

Detailed information on the internal stakeholders can be seen in Table 5. For this group, the interviews were conducted with the internal stakeholders of three Islamic banks, with a total of 20 from both the management levels and employees. Three main aspects were discovered from this group, as shown in column 5.2, 5.3, and 5.4) of Table 5. 


\section{a. Reasons for Working for Islamic Banks}

There were three reasons for working in IB. The first reason was assignment by the parent bank ( 3 cases out of the 20) as principals or vice directors; the second reason was following a request to move from a conventional parent bank to an Islamic one, underlined by the belief that interest or usury is prohibited (5/20), which is coined as migrating to a more religious life (hijra); and the third reason was that they opted to work at an Islamic bank from the beginning, either because they preferred the Sharia way, or simply because at the time there were vacancies in Islamic banks (12/20).

Table 5.

Internal Stakeholder Perspectives in IB

\begin{tabular}{|c|c|c|c|}
\hline $\begin{array}{l}\text { Position } \\
\quad(5.1)\end{array}$ & $\begin{array}{c}\text { Reasons for } \\
\text { Working at an } \\
\text { IB (5.2) }\end{array}$ & $\begin{array}{c}\text { Interest } \\
\text { and Fulfilment } \\
\text { of Expectations (5.3) }\end{array}$ & $\begin{array}{c}\text { Perspectives of Islamic } \\
\text { Banking (5.4) }\end{array}$ \\
\hline $\begin{array}{ll} & \text { Board of } \\
& \text { Directors (3) } \\
\text { - } & \text { Manager (11) } \\
\text { - } & \text { Employee (6) } \\
\text { - } & \text { Total } \\
& \text { number of } \\
\text { respondents: } \\
20\end{array}$ & 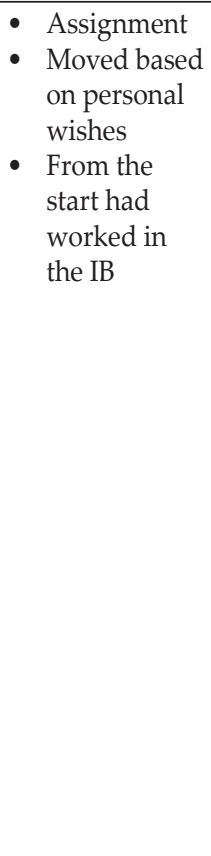 & $\begin{array}{l}\text { - Profitability, } \\
\text { liquidity, and } \\
\text { excellent asset } \\
\text { quality } \\
\text { - Salaries, allowances, } \\
\text { and comfortable } \\
\text { facilities } \\
\text { - HR competency } \\
\text { and improvement } \\
\text { infacilities } \\
\text { - Awards for } \\
\text { innovation and } \\
\text { creativity } \\
\text { - Participatation in the } \\
\text { fight for an Islamic } \\
\text { economy }\end{array}$ & $\begin{array}{l}\text { - Similar to other banks or companies, } \\
\text { including the 3P (people-profit-planet) } \\
\text { principle } \\
\text { - Optimistic that IB will move forward } \\
\text { with the right strategy, innovation, } \\
\text { and government support } \\
\text { - IIB with capital between IDR 5-30 } \\
\text { trillion just in an IB indicates that the } \\
\text { capital is not strong enough, so the } \\
\text { price per unit is high } \\
\text { It is aligned with Sharia principles } \\
\text { because there are already DPS, MUI, } \\
\text { and OJK but they must continue the } \\
\text { process. } \\
\text { Making transactions and working in } \\
\text { IB will lead to benefits in the world } \\
\text { hereafter } \\
\text { Weaknesses: market-share, Islamic } \\
\text { finance literacy, expansion of outlets, } \\
\text { IT, and HR development } \\
\text { Government support has increased } \\
\text { and prioritised IB, especially that } \\
\text { related to Islam, such as Islamic Court } \\
\text { (PA), madrasa, and hajj }\end{array}$ \\
\hline
\end{tabular}

\section{b. Interest and fulfilment of expectations}

Five points were made by the respondents regarding their interest in and expectations of the IB where they worked. The first was good profitability and good asset quality. In particular, this is of interest to the Main Director and Vice President; however, in general, it affects the benefits of all internal stakeholders. Profitability and quality of assets will affect the future of Islamic banks in general, while also affecting the well-being of internal stakeholders in particular. This view serves as evidence for the development of Islamic banks, especifically for those who intentionally move or "hijra" to IB. However, based on the interview findings 
on the level of fulfilment of this interest, in general the respondents stated that it has not been entirely fulfilled.

The second area of interest relates to excellent salaries, benefits, and facilities. While this point was conveyed explicitly by the employees, it can be assumed that all internal stakeholders have an interest in this. The third area concerns facilities for enhancing HR competencies, on which there appear to be different perspectives from top management and employees. Top management conveyed the impression that their focus in this category was undoubtedly related to leadership programmes, while on the other hand the employees stated that overall the training and development programmes were sufficient, even though less extensive than those of conventional banks.

The fourth point of interest was appreciation of innovation and creativity. This has started to gain the attention of the top management of market leaders and challengers. There are several improvement programmes in IB, including ones on knowledge management and competition program on innovation. This category has not been sufficiently explored for the regional bank because the programme there is already sufficient to accommodate the needs of the regional market, which is not as complex as the central one. The last area of interest is participation in Indonesia's Islamic economic development. This point was the focus of the respondents who had moved to IB because of "hijra" from top management, middle management, and employees. This category of respondents believed that joining IB was a manifestation of their religiosity and that involvement in the Islamic economy was a part of worship.

\section{c. Perspectives of internal stakeholders regarding IIB}

Based on the considerable information collected, we noted seven main perspectives from the internal stakeholders regarding Islamic banks.

The first, which is related to top management, is that Islamic banks are similar to conventional banks or other companies in that they search for profit and incorporate the people-planet-profit (3P) principle in their operations. The only distinguishing factors between IB and CB are their visions and basic operations .

In general, the internal stakeholders were fairly optimistic that IB could progress, as long as their operational activities were aligned with the appropriate strategy, innovation, and government support. On the other hand, the number of IBs with capital 5-30 billion (book three -Indonesaian term) is still limited to one, so based on this information it can be stated that the level of IB capital is not sufficiently robust. This weakness may affect many aspects of IB development, such as products (high price per unit), human resources (limited development), and operations (limited infrastructure and facilities).

All the respondents believed that Islamic banks followed the Sharia guidelines and standards as set by DPS, MUI, and OJK. However, there is still a need to continue in the process of maintaining Sharia and developing monitoring tools. This perspective is held by most internal stakeholders. It is believed that transacting and working in IIB will benefit one's afterlife. The respondents felt calm working in IB because it is aligned with their beliefs. Moreover, they believed that IIB would become a blessing to the universe. 
The respondents also stated that IBs still had many shortcomings, especially pertaining to market share, Islamic financial literacy, and the ATM infrastructure for access to banking, which are all still below 10\% compare to CB. Other drawbacks are the lack of outlet expansion, IT, and human resource development. They perceived that government support had increased in recent years, but that the government was not sufficiently Sharia-oriented, especially in matters related to religious courts, Islamic education institutions, zakat-infaq-shadaqoh, and Hajj and Umrah.

\subsubsection{Customer and non-customer stakeholders}

This group consisted of 23 customer and non-customer interviewees (Table 6). Included in the category (column 6.1) are IB customers (6/23), CB customers (6/23), both IB and CB customers (3/23), entrepreneurs using IB, CB, or both (3/23), and non-Muslim customers (3/23). In the latter, all the respondents were CB customers. Three perspectives were discovered from this group (columns 6.2, 6.3, and 6.4).

Table 6.

Customer and Non-customer Stakeholder Perspective on IB

\begin{tabular}{llll}
\hline $\begin{array}{l}\text { Stakeholder category } \\
\text { (6.1) }\end{array}$ & $\begin{array}{l}\text { Factors Influencing } \\
\text { Bank Selection (6.2) }\end{array}$ & $\begin{array}{c}\text { Views on IB } \\
\mathbf{( 6 . 3 )}\end{array}$ & $\begin{array}{l}\text { Customer Journey with } \\
\text { Islamic Banking (6.4) }\end{array}$ \\
\hline - IB customer (6) & - Accessibility & : Pro & ・ Observer \\
- CV customer (6) & - Networking & - Contra & - Interest \\
- Both (6) & - Services \& Products & - Neutral & : Satisfied customer \\
- Entrepreneur (3) & - Marketing & & - Unsatisfied customer \\
- Non- Muslim (3) & - Safety & & \\
Total respondents: 23 & - Religious belief & & \\
\hline
\end{tabular}

\section{a. Fundamental reasons for choosing a bank}

The first questions asked were which bank they were customers of and and how satisfied they were with their choice. From these questions, the reasons for choosing a bank were explored. Out of the 23 interviewees with different backgrounds, six reasons were given for bank cloice. The first reason was accessibility (17/23), which refers to the proximity of branches, the ease of finding ATMs, and the accessibility of online banking. Common complaints against Sharia banks regarding accessibility included the limited number of ATMs, and the number of branch locations that were difficult to access, especially for those working (employers and employees), who had limited time to go to the bank. Not all IBs have good e-banking and therefore entrepreneurs still need to make banking transactions at bank offices.

The second reason was networking (13/23). Entrepreneurs choose accounts that are widely used by buyers and suppliers, and buyers choose banks that are widely used by sellers. Exclusive features such as games and stock trading were also noted. The third reason was services and products (12/23). Although in general bank products are almost identical, banks' foresight in designing services and products is a reason for choosing them. Almost all the respondents had 
an account in a CB because its products are attractive and satisfactory services are provided both offline and online. However, what is interesting is that two entrepreneurs who were not IB customers initially opened an IB account because they were interested in an IB product that supported their business, namely the ease of tracking transactions from online buyers. However, they complained that the IB product was unclear, in terms of the put Arabic names, system, and differentiation from conventional banks; in addition, the service provided by one of the IBs was less professional.

The fourth reason was marketing (8/23). In general, all customers consider the marketing of IBs to be less aggressive, but less effective and unable to reach customers. Some respondents did receive information regarding IB because they worked at or attended Islamic institutions; however, most felt that they had never been directly approached by the IB marketing team, and generally only knew about the IB indirectly, through advertisements, through existing buildings, or by looking for information themselves. Especially in the case of entrepreneurs, all felt that they have never been contacted by the marketing team, so they had to find out about IB products themselves. Some respondents even stated that when they made a search, they did not receive adequate information or received poor service.

The fifth reason was security (7/23). This point was deemed necessary by several respondents, while others considered that in general all the banks were guaranteed and protected by the government. Safety in this case includes guaranteed asset storage; transaction security, especially in online banking; and transparency as a guardian of security. There were several complaints from respondents about one of the IBs regarding unprofessional bookkeeping. The sixth reason was religious belief (5/23). Three types of respondents fall into this criterion, namely those who chose to only use IB based on their religious beliefs; those who chose to use IB together with CB financial services; and those who refused to use IB (non-Muslim customers).

\section{b. Customers' views of IB}

Customers' views of Islamic banks can be divided into three types. The first view is supportive of Islamic banking IB (12/23), citing reasons such as (a) the religious belief that usury is prohibited and that IB is fully Sharia-compliant; (b) the belief that as usury is haram, IB is an alternative solution/way out while progressing towards halal or greater Sharia; (c) migration/"hijra", including economically; and (d) being forced to use CB due to networking needs and IB access difficulties.

The second point of view relates to customers who are against IB (6/23). An interesting phenomenon in this category first concerns a non-Muslim interviewee who clearly stated that he would not become an IB customer because he felt marginalised. According to this group of respondents, IB was part of the teachings Islamic values, and there was also a fear that later religious issues would be questioned. Two other non-Muslims, however, remined neutral; (b) Non-Muslims who adhered to a particular sect and thought that IB was as haram as conventional banks.

The third point of view relates to customers who are neutral towards IB (5/23). There were several groups who claimed to be neutral. These included (a) most of 
theentrepreneurs, who stated that it did not matter which bank was used as long as it provided convenience, service and financing; (b) customers who believed that usury was haram, but because networking requires using conventional banks, they used these but did not accept any interest; and (c) two of the non-Muslim interviewees, who stated that they were neutral regarding IB as long as it met their needs.

\section{c. Customer journey with IB}

There were four levels of experience that customers had in their engagement with IB. The first was customers as observers (23/23). In general, all the respondents were initially observers. They realised that there were IB, either from the news or advertisements, or were aware of the existence of an IIB building or outlet. There are two kind of observers; those who are well informed so they are interested in becoming customers, and those who are not well informed, so remain observers either because of a wrong or neutral impression, but have no access to IB.

The second level was customer interest (19/23). Observers of the first journey, i.e. those who are well informed, will consequently be interested in IB. There are several forms of interest, including looking for useful information via the internet, asking people whom they perceive know about Ib, and calling or visiting an IIB. Customers who make this second journey can be divided into two groups: those who are well informed, so choose to join the IB, or those who are not well informed, so are not interested or delay their interest.

The third level was satisfied customers (8/23). The first kind of interested customer, namely those who later become an IIB client, can also be divided into two types, namely those who are satisfied and those who are unsatisfied. Several reasons account for customers' being satisfied, relating to their beliefs or fulfilment of their service needs. Satisfied customers will continue to be IB customers, and it is possible to expand their use of banking products. The fourth level is unsatisfied customers (7/23). The second kind of IB customer are those who are dissatisfied. This dissatisfaction was caused by, among others reasons, difficulties in accessing IB both online and offline, because they had to use CB networking; for example, for salaries from offices. Some were disappointed with IB services in terms of safety, transparency, and product ambiguity.

The interview findings show that the factors that influence bank selection in general apply to both CB and IB. Only a small proportion of respondents chose banks because of their beliefs, and this also applies to the customer journey. In general, the factors that affect customer satisfaction with a bank are the same for IB and CB. There is the only additional peace of mind for those who believe that IB is part of their religion.

\subsection{Stakeholder Analysis}

After going through the identification and classification stages of all the IB stakeholders, the next step was to conduct the stakeholder analysis. This step was taken because a company has multiple stakeholders and has to choose which to prioritise in the distribution of resources, while still paying attention to the 
other stakeholders. The attributes of stakeholder salience were anlysed based on the results of the interviews (Table 7). Salience is defined as the degree to which managers give priority to competing stakeholder claims. The greater the power $(\mathrm{P})$, legitimacy $(\mathrm{L})$, and urgency $(\mathrm{U})$ attributes, the higher the stakeholder salience (Mitchell et al., 1997).

Table 7.

Stakeholder Salience Classifications

\begin{tabular}{lccc}
\hline Group & Stakeholder & Attributes & Classification \\
\hline \multirow{2}{*}{ Latent } & NGO & $\mathrm{U}$ & Demanding \\
& Media & $\mathrm{L}$ & Discretionary \\
\hline \multirow{2}{*}{ Expectant } & Competitor & $\mathrm{P}, \mathrm{U}$ & Dangerous \\
& Society & $\mathrm{P}, \mathrm{L}$ & Dominant \\
\hline \multirow{4}{*}{ Definitive } & Management & $\mathrm{P}, \mathrm{L}, \mathrm{U}$ & Definitive \\
& Employee & $\mathrm{P}, \mathrm{L}, \mathrm{U}$ & Definitive \\
& Customer & $\mathrm{P}, \mathrm{L}, \mathrm{U}$ & Definitive \\
& Regulator & $\mathrm{P}, \mathrm{L}, \mathrm{U}$ & Definitive \\
\hline
\end{tabular}

In the IB context, four definitive stakeholders dominate companies' stakeholder list. More attention should be paid to definitive groups in the context of limited time, energy, and company resources (Mitchell et al., 1997). However, companies should not forget about latent and expectant stakeholders because they can become definitive stakeholders in line with business dynamics over time.

There is a matrix of dependence typology that is frequently used to assess the extent to which a stakeholder is dependent on the company (Frooman, 1999). Discussions with IB management revealed that amongst the many stakeholders associated with the company, only a few had a high degree of dependence (as shown in Table 8). In our analysis, competitors were divided into direct and indirect ones, namely fellow Islamic banks as direct competitors, and conventional banks as indirect competitors.

Table 8.

Typology of Dependence between Stakeholders and Companies

\begin{tabular}{lccc}
\hline & & \multicolumn{2}{c}{ Does the company depend on stakeholders? } \\
\cline { 2 - 4 } & & No & Yes \\
\hline \multirow{2}{*}{$\begin{array}{l}\text { Does the company } \\
\text { depend on } \\
\text { stakeholders? }\end{array}$} & No & Low Interdependence & Firm Power \\
& & Competitors (Conventional Banking); & Direct Competitors (IB) \\
& Yes & Society; Media & High Interdependence \\
& & Stakeholder Power & Management \\
& & Government/Regulators & Employees \\
\hline
\end{tabular}

Companies should focus their attention on the stakeholder power and high interdependence quadrants, due to the strength of the stakeholders and their high 
dependence on the company. Following the summary analysis of the typology shown in Table 8 above, the two quadrants hold a relatively large proportion of dependence. By focusing attention on these two groups, management can make the most of its resources. The other two groups should be kept in view, but not be the main focus.

Table 9.

\section{Power Interest Grid Analysis}

\begin{tabular}{|c|c|c|c|}
\hline & \multicolumn{2}{|r|}{ Interest } \\
\hline & & Low & High \\
\hline \multirow{4}{*}{ Power } & & Minimum effort & Well informed \\
\hline & Low & NGOs/ IB Associations & Competitors \\
\hline & & Society & Media \\
\hline & High & $\frac{\text { Keep satisfied }}{\text { Customers }}$ & $\begin{array}{c}\text { Key Players } \\
\text { Management, Employees, Regulators }\end{array}$ \\
\hline
\end{tabular}

The subsequent analysis used power interest grid analysis, which provides guidelines for classifying stakeholders according to the relationship between power and their interests (Gardner, 1997). In this study, this was analysed in the context of IB to suggest what needed to be done to serve the interests of each stakeholder group, as shown in Table 9. The quadrant's key player dominates the number of IB stakeholders and plays a significant role in influencing strategic and implementation considerations in the business; therefore, those in this position are the critical stakeholders on which IB should focus. Nevertheless, it is crucial to keep customers satisfied, because they have high power and influence within the company, but have low interest given that they have many alternative banks to choose from. Their moves to other banks will obviously have ramifications for Islamic banks.

This sub-chapter has analysed stakeholders, using the three tools (stakeholder salience, typology of dependence, power interes grid analysis) above. The results show that the stakeholders on which attention from IB should be focused are management, employees, regulators, and of course customers. Other stakeholders must be considered, but the effort and resources directed at them do not need to be as great as those used for the four key stakeholders (Preston \& Sapienza, 1990).

\section{CONCLUSION AND RECOMMENDATIONS}

\subsection{Conclusion}

This study has explored which stakeholders have the most influence on IB, their views on IB performance, and what strategies should be taken to handle them and improve IB performance. The study results are different from those of previous studies on stakeholder analysis, which have tended to focus on exploring how stakeholders view Islamic banks' objectives, whether they are profit-oriented or social welfare-oriented. Previous studies also are quantitative in nature (Ahmed, 2016; Dusuki \& Abdullah, 2007; Khan \& Ramzan, 2015). 
Several interesting findings have been made regarding internal and external stakeholders' views of the performance of Islamic banks. In general, internal stakeholders view the performance of IB positively. Half of the employees stated that they had chosen to work in IB because of their religious beliefs, migration or "hijra" from CB to IB, or that IB was their choice from the beginning. These internal stakeholders' reasons for working in IB will benefit IB if they are handled properly. Such benefits may include high engagement, high loyalty, and the possibility to overcome any discontent related to salary or career development as employees believe they are working as part of their worship of God.

Interview result with Internal stakeholders provide three critical notes on management, namely products related to innovation and high price per unit; human resource management related to employee development and rewards that are very different from $\mathrm{CB}$; and infrastructure, both physical and technological, which is still minimal, thus reducing customer accessibility. Apart from these findings internal stakeholders believe that Sharia banks will be able to face challenges and survive in the future. In addition, they believe that Sharia banks are compliant with Sharia because they follow the rules and are supervised by relevant regulatory bodies.

As external stakeholders, customers have diverse views and experiences of $\mathrm{IB}$, from the most supportive to the most negative. The most supportive are from customers with religious beliefs, but also from those who are satisfied with the products and services. Any rejection of IB could be due to religious factors, either by non-Muslims who consider IB to be a form of Islamic missionary, or Muslims who do not believe that IB is truly Sharia, or due to dissatisfaction with IB products and services. Those customers in the middle are generally looking for a bank that meets their needs regardless of whether it is Islamic or conventional.

The research implies that stakeholder analysis can show whether an organisation's performance is well received by a community or not, which is in line with the work of Greenley et al. (2005), He et al. (2011), and Luk et al. (2005). In Indonesian Islamic banking, IB performance is considered good from the internal stakeholder perspective, although there are still some recommendationsfor improvement. Meanwhile, from the external stakeholder perspective, whether or not IB performance is considered good depends on the products and services, which is similar to CB. However, the value of religious belief is one of the assessment indicators. Based on the assessment of organisational performance using stakeholder analysis, a revitalisation strategy to improve IB performance is proposed in the following section.

\subsection{Managerial Implications, Limitations, and Future Study Directions}

Numerous recommendations can be made. Using stakeholder analysis, the study has narrowed down the main stakeholders to four types that are most influential on IB: employees, management, customers, and regulators/government. With limited resources, companies must establish priorities to serve and fulfil their interests. Managers can therefore gain benefit from this study.

First, employees are the drivers of a company's operating activities. Two aspects that should be considered are employee development through training, 
and development and encouragement of innovation. Appreciation of employee performance needs to be promoted. Apart from material rewards, appreciation can also be related to performance. For example, employees who joined IB because of "hijra" should be appreciated with recognition and by making them influencers in forming a more religious corporate culture. It has been proven that employees driven by belief have a better work ethic.

Second, management plays a critical role in the formulation of corporate strategy. Improvement of all aspects of management, be it related to finance, human resources, marketing, or operations, must be made. Third, IB customer position is not a key player in the industry, but they must be satisfied customers. This position is very vulnerable for IB because customers have high bargaining power. If they withdraw their custom, this will affect IB; in addition, they also have the freedom to choose whichever bank that meets their needs. Due to its vulnerability, IB must prioritise meeting customer needs if they do not want to be abandoned.

IB has received fairly significant support from the government. In recent years, this support has been expanding, some of which is from the National Committee for Sharia Economics and Finance (KNEKS) and the conversion of several regional banks. The government has released statements indicating that there are plans to merge several IBs to increase their assets and resources. However, this support must be more concrete; for instance, by giving IB priority to funds related to Islamic education institutions, religious courts, Umrah and Hajj, and other government funds.

The limitations of the study offer opportunities for further research. The paper has explored stakeholders' views of IB but has not linked them to stakeholder choices or behaviour. It hs therefore not been able to show the direct impact of stakeholders' views on organisational performance. Future studies could consider, for example, the amount of savings and investment from customers, employee performance, or employee ethics, to serve as a basis for linking the level of customer assessment of IB with the value of investment within it. Likewise, concerning employees, future studies could relate their views of IB and their performance, so that more specific policies can be formulated.

The research has found that the religious values promoted by IB can increase company value, but at the same time can also reduce the interest in using IB. It is necessary to further investigate the appropriate strategies to place this religious value in society, in order to be able to formulate policies for both homogeneous and heterogeneous markets. This approach could also be applied to other organisations that have special visions and values, not just related to religion, in order to enter markets with multiple values.

\section{REFERENCES}

Ahmed, I. (2016). Aspirations of an Islamic bank: An exploration from stakeholders' perspective. International Journal of Islamic and Middle Eastern Finance and Management, 9(1), 24-45.

Ascarya, Rahmawati, S., \& Sukmana, R. (2017). Measuring the Islamicity of Islamic bank in Indonesia and other countries based on Shari'ah objectives. 11th Islamic 
Conference on Islamic Economics and Finance, Kuala Lumpur, Malaysia, October 11-13, 2016 (pp. 1-30).

Atti, G., Galantini, V., \& Sartor, M. (2019). Stakeholder management. In Quality Management: Tools, Methods and Standards. https://doi.org/10.1108/978-1-78769801-720191002 if chapter in a book, give editor/s, city of publication and publisher

Beck, T., Demirgüç-Kunt, A., \& Merrouche, O. (2013). Islamic vs. conventional banking: Business model, efficiency and stability. Journal of Banking and Finance, 37(2), 433-447.

Bedoui, H. E., \& Mansour, W. (2015). Performance and Maqasid al-Shari'ah's pentagon-shaped ethical measurement. Science and Engineering Ethics, 21(3), 555-576.

Berman, S. L., Wicks, A. C., Kotha, S., \& Jones, T. M. (1999). Does stakeholder orientation matter? The relationship between stakeholder management models and firm financial performance. The Academy of Management Journal, 42(5), 488-506.

Bhattacharya, C. B., Korschun, D., \& Sen, S. (2009). Strengthening stakeholdercompany relationships through mutually beneficial corporate social responsibility initiatives. Journal of Business Ethics, 85(2 Supplement), 257-272.

Brugha, R., \& Varvasovszky, Z. (2000). Stakeholder analysis: A review. Health Policy and Planning, 15(3), 239-246.

Bunn, M. D., Savage, G. T., \& Holloway, B. B. (2002). Stakeholder analysis for multi-sector innovations. Journal of Business and Industrial Marketing, 17(2-3), 181-203.

Butina, M. (2013). A narrative approach to strategy-as-practice. Business History, 55(7), 1143-1167.

Castillo-Montoya, M. (2016). Preparing for interview research: The interview protocol refinement framework. Qualitative Report, 21(5), 811-831.

Clarkson, M. B. E. (1995). A stakeholder framework for analyzing and evaluating corporate social performance. Academy of Management, 20(1), 92-117.

Creswell, J. W. (2013). Qualitative inquiry and research design: Choosing among five approaches. Thousand Oaks, California: SAGE Publications, Inc.

de Colle, S. (2005). A stakeholder management model for ethical decision making. International Journal of Management and Decision Making, 6(3-4), 299-314.

Denzin, N. K. (2018). Strategies of multiple triangulation. In N. K. Denzin (Ed.), The research act; $A$ theoretical introduction to sociological methods. New York: Routledge.

Dusuki, A. W., \& Abdullah, N. I. (2007). Why do Malaysian customers patronise Islamic banks? International Journal of Bank Marketing, 25(3), 142-160.

Eesley, C., \& Lenox, M. J. (2006). Firm responses to secondary stakeholder action. Strategic Management Journal, 27(8), 765-781.

Eljelly, A. M. A., \& Abdelgadir Elobeed, A. (2013). Performance indicators of banks in a total Islamic banking system: The case of Sudan. International Journal of Islamic and Middle Eastern Finance and Management, 6(2), 142-155.

Faliza, N. (2016). CSR and Islamic banking performance in Aceh: The role of innovation as mediation. Journal of Management and Marketng Review, 1(June), 45-56. 
Freeman, R. E. (1984). Strategic management: A stakeholder approach. Boston, MA: Pitman Publishing.

Freeman, R. E. (2015). Strategic management: A stakeholder approach. New York: Cambridge University Press.

Friedman, A. L., \& Miles, S. (2002). Developing stakeholder theory. Journal of Management Studies, 39(1), 1-21.

Frooman, J. (1999). Stakeholder influence strategies. Academy of Management Review, 24(2), 191-205.

Frow, P., \& Payne, A. (2011). A stakeholder perspective of the value proposition concept. European Journal of Marketing, 45(1), 223-240.

Gardner, J. R. (1997). Liberty, community and the constitutional structure of political influence: A reconsideration of the right to vote. University of Pennsylvania Law Review, 145, 893-985.

Gardner, J. R., Rachlin, R., \& Sweeny, A. (1986). Handbook of strategic planning. Hoboken, NJ: J Wiley.

Greenley, G. E., Hooley, G. J., \& Rudd, J. M. (2005). Market orientation in a multiple stakeholder orientation context: Implications for marketing capabilities and assets. Journal of Business Research, 58(11 Spec. Iss.), 1483-1494.

Gustani. (2013). Analisis Tingkat pengungkapan kinerja sosial bank syariah berdasarkan Islamic social reporting index (Indeks ISR) [Analysis of disclosure level of the social performance of Islamic banks based on the Islamic social reporting index (ISR Index)]. Jurnal Akuntansi dan Auditing Indonesia, February 2013. https://doi.org/10.13140/RG.2.1.1516.3128

Hanif, M., Tariq, M., Tahir, A., \& Wajeeh-ul-Momeneen. (2012). Comparative performance study of conventional and Islamic banking in Pakistan. International Research Journal of Finance and Economics, 83, 62-72. https://ssrn. com/abstract $=1959950$

Harfiah, L. M., Purwati, A. S., \& Ulfah, P. (2016). The impact of ROA, BOPO, and FDR to Indonesian Islamic bank's mudharabah deposit profit sharing. Etikonomi, 15(1), 19-30.

Hassan, M. K., \& Aliyu, S. (2018). A contemporary survey of Islamic banking literature. Journal of Financial Stability, 34(2018), 12-43.

He, X., Zhang, X., Li, X., \& Piesse, J. (2011). Stakeholder orientation and organisational performance in an emerging market. Journal of General Management, 36(3), 67-91.

Huda, N., Sabrina, I., \& Zain, E. (2013). Pengukuran kinerja perbankan syariah dengan pendekatan balance scorecard [The measurement of Islamic banking performance with a balanced scorecard approach]. Jurnal Etikonomi, 12(1), 2132.

Hult, G. T. M., Mena, J. A., Ferrell, O. C., \& Ferrell, L. (2011). Stakeholder marketing: a definition and conceptual framework. AMS Review, 1(1), 44-65.

Johnes, J., Izzeldin, M., \& Pappas, V. (2014). A comparison of performance of Islamic and conventional banks 2004-2009. Journal of Economic Behavior and Organization, 103(Supplement July), S93-S107.

Khan, M. M., \& Ramzan, M. (2015). Perceptions of stakeholders on Islamic banking in Pakistan. Journal of Islamic Business and Management, 5(2), 99-116. 
Lipka, M., \& Hackett, C. (2017). Why Muslims are the world's fastest-growing religious group. In Pew Research Centre, Washington, DC (April 6, 2017). https:// www.pewresearch.org/fact-tank/2017/04/06/why-muslims-are-the-worldsfastest-growing-religious-group/

Littau, P., Jujagiri, N. J., \& Adlbrecht, G. (2010). 25 Years of stakeholder theory in project management literature (1984-2009). Project Management Journal, 41(4), 17-29.

Luk, C. L., Yau, O. H. M., Tse, A. C. B., Sin, L. Y. M., \& Chow, R. P. M. (2005). Stakeholder orientation and business performance: The case of service companies in China. Journal of International Marketing, 13(1), 89-110.

Magaldi, D. B. M. (2020). Semi-structured interviews. In V.Zeigler-Hill \& T.K. Shackelford (Eds.), Encyclopedia of personality and individual differences. Cham, Switzerland: Springer.

Matos, S., \& Silvestre, B. S. (2013). Managing stakeholder relations when developing sustainable business models: The case of the Brazilian energy sector. Journal of Cleaner Production, 45(April), 61-73.

Merriam, S. B., \& Tisdell, E. J. (2016). Qualitative research: A guide to design and implementation, 4th Edition. San Francisco: John Wiley \& Sons, Inc.

Minoja, M. (2012). Stakeholder management theory, firm strategy, and ambidexterity. Journal of Business Ethics, 109(1), 67-82.

Mitchell, R.K, Agle, B.R. \& Wood, D. (1997). Toward a theory of stakeholder identification and salience: Defining the principle of who and what really counts. Academy of Management Review, 22(04), 853-886.

Mohammed, M. O., Tarique, K. M., \& Islam, R. (2015). Measuring the performance of Islamic banks using maqāṣid-based model. Intellectual Discourse, 23(Special Issue 2015), 401-424.

Mollah, S., \& Zaman, M. (2015). Shari'ah supervision, corporate governance and performance: Conventional vs. Islamic banks. Journal of Banking and Finance, 58(September 2015), 418-435.

Nvivo. (2018). Nvivo 12 for Windows. In NVivo qualitative data analysis Software; QSR International Pty Ltd. https://doi.org/10.1887/0750306920/b833c1

OJK. (2019). Statistik Perbankan Syariah. Www.Ojk.Go.Id.

Payne, A., Ballantyne, D., \& Christopher, M. (2005). A stakeholder approach to relationship marketing strategy. The development and use of the "six markets" model. European Journal of Marketing, 39(7/8), 855-871.

Pedrini, M., \& Ferri, L. M. (2019). Stakeholder management: A systematic literature review. Corporate Governance (Bingley), 19(1), 44-59.

Perrini, F., \& Tencati, A. (2006). Sustainability and stakeholder management: The need for new corporate performance evaluation and reporting systems. Business Strategy and the Environment, 15(5), 296-308. https://doi.org/10.1002/ bse. 538

Preston, L. E., \& Sapienza, H. J. (1990). Stakeholder management and corporate performance. The Journal of Behavioral Economics, 19(4), 361-375.

Puspaningtyas, L. (2019). Tingkat Inklusi Keuangan Syariah Indonesia Turun I Republika Online. Republika.

Rafiq, M. R. I. (2016). Determining bank performance using CAMEL rating: A comparative study on selected Islamic and conventional banks in Bangladesh. Asian Business Review, 6(3), 151-160. 
Ranängen, H., \& Zobel, T. (2014). Revisiting the "how" of corporate social responsibility in extractive industries and forestry. Journal of Cleaner Production, 84(1), 299-312.

Rodoni, A., Salim, M. A., Amalia, E., \& Rakhmadi, R. S. (2017). Comparing efficiency and productivity in Islamic banking: Case study Indonesia, Malaysia and Pakistan. Al-Iqtishad: Journal of Islamic Economics, 9(2), 227-242.

Rosly, S. A., \& Abu Bakar, M. A. (2003). Performance of Islamic and mainstream banks in Malaysia. International Journal of Social Economics, 30(11-12), 12491265.

Rusydiana, A. S., \& Hasib, F. F. (2019). Islamic banking selection criteria: Case in Indonesia using analytic network process. Economica: Jurnal Ekonomi Islam, 10(1), 165-188.

Savin-Baden, M., \& Van Niekerk, L. (2007). Narrative inquiry: Theory and practice. Journal of Geography in Higher Education, 31(3), 459-472.

Siraj, K. K., \& Sudarsanan Pillai, P. (2012). Comparative study on performance of Islamic banks and conventional banks in GCC region. Journal of Applied Finance $\mathcal{E}$ Banking, 2(3), 123-161.

Soto, C. F., Quintana, L. A. M., \& Rodríguez, P. V. (2018). Effect of stakeholdersoriented behavior on the performance of sustainable business. Sustainability (Switzerland), 10(12), 1-27.

Syafii Antonio, M., Sanrego, Y. D., \& Taufiq, M. (2012). An analysis of Islamic banking performance: Maqashid index implementation in Indonesia and Jordania. Journal of Islamic Finance, 1(1), 12-29.

Tantalo, C., \& Priem, R. L. (2016). Value creation through stakeholder synergy. Strategic Management Journal, 37(2), 314-329.

Tariq, M., Ahmed, A., Rafi, S. K., \& Ahmed, S. (2014). Investigating the impact of balanced scorecard on performance of business: A study based on the banking sector of Pakistan. IBT Journal of Business Studies (Formerly Journal of Management \& Social Sciences), 9(1), 125-136.

Varvasovszky, Z., \& Brugha, R. (2000). How to do (or not to do)...: A stakeholder analysis. Health Policy and Planning, 15(3), 338-345.

Waddock, S., \& Smith, N. (2000). Relationships : The real challenge of coorporate global citizenship. Business and Society Review, 105(1), 47-62.

Wojewnik-Filipkowska, A., Dziadkiewicz, A., Dryl, W., Dryl, T., \& Bęben, R. (2019). Obstacles and challenges in applying stakeholder analysis to infrastructure projects: Is there a gap between stakeholder theory and practice? Journal of Property Investment and Finance, 39(3), 199-222.

Yin, R. . (2016). Qualitative research from start to finish. Second Edition. New York: The Guilford Press.

Zafar, M. B., \& Sulaiman, A. A. (2020). Measuring corporate social responsibility in Islamic banking: What matters? International Journal of Islamic and Middle Eastern Finance and Management, 13(3), 357-388. 
This page is intentionally left blank 